\title{
Some
}

\section{Bird Observations along the La Ronge- Churchill River and Hanson Lake Roads}

by Douglas E. and Dorothy $\mathbf{R}$. Wade, Regina

Late in the summer of 1961 we made some interesting observations of bird life on a short trip (August 31-September 4) to La Ronge and up to Otter Rapids, Mile 54 on the La Ronge-Churchill River Road (Mile references are to the "Mile" markers along the road, beginning with La Ronge as zero). The La Ronge-Churchill River Road, formerly known as the La RongeUranium City Road, now extends to Otter Rapids where a bridge crosses the Churchill River. Records from this area and the Hansen Lake Road are limited; no attempt was made to search the literature. However, we felt it was worthwhile to publish our observations.

August 31, 1961, was very warm. En route north, we saw a Turkey Vulture soaring over the South Saskatchewan River about six miles north of St. Louis. On the same day, at the town of La Ronge, two Pigeon Hawks were observed flying over the muskeg (Mile 1). At Mile 1.5 there were a dozen Ravens and about the same number of Common Crows, presumably feeding at a nuisance grounds.

At Missinipi town-site (Mile 51) on the Churchill River, where we camped for one night, a Great Gray Owl treated us to a variety of calls and a low-level flight over our camp. Near by, earlier that evening, we had seen an Indian boy with his dog, and when we first heard the owl, we thought it was the boy "voicewhistling" for his dog; then later the owl's calls reminded us of the cries. of a Snowshoe Rabbit in distress. It was not until the owl flew over that we were able to pin down the source of the calls. The owl called while in flight as well as when perched.

September 1 started out warm, but the temperature dropped steadily all day and there were intermittent showers.. One mature Bald Eagle was seen while we were canoeing about four miles east of MacKay Lake (Mile 37) on an un-named lake near Contact Lake. Also observed while canoeing on a route east of MacKay Lake were two adult and one immature Goshawks, one Blackcapped Chickadee, two Rubycrowned Kinglets, and at least three Belted Kingfishers. On Contact Lake there was one adult Common Loon, accompanied by two young loons, which were about three-fourths grown. The loons swam away from as and did not attempt to fly.

September 2 was cold and windy all day, with morning temperatures ranging about $38^{\circ}$. At MacKay Lake we caught a passage of migrating Canada Geese, when a flock of 60 in $\mathrm{V}$-formation came over, moving rapidly southward. One Mourning Dove flew across the road at about Mile 33. There was a small wooded muskeg adjacent to the road on one side. At Lynx Lake along the Road, we saw three Water Pipits. They accompanied us southward on the road for at least three miles. Three Eastern Kingbirds worked near us, catching insects at Lynx Lake. At a muskeg pond, partly filled in with road fill (Mile 27), we had an American Golden Plover in fall plumage) under careful observation with binoculars for at least half an hour. The plover was feeding in the wet silt shore of fill material and muskeg push-up. The same pond held three female Buffleheads.

Farther down the road along a parallel stretch of Waden Bay (an arm of Lac La Ronge), we were able to spot 11 Pintails, eight Lesser Scaup, 10 Mallards, five Gadwalls, and an unlisted number of Redheads, Ring-necked Ducks, and Greenwinged Teal. The water in the bay was low and vegetation rank and high, making it impossible to get precise counts on all the ducks, so there were undoubtedly many more unrecorded.

September 3 was sunny and cold, with temperatures below and near freezing. A Peter Gregg's home in La Ronge, a Roughlegged Hawk flew 


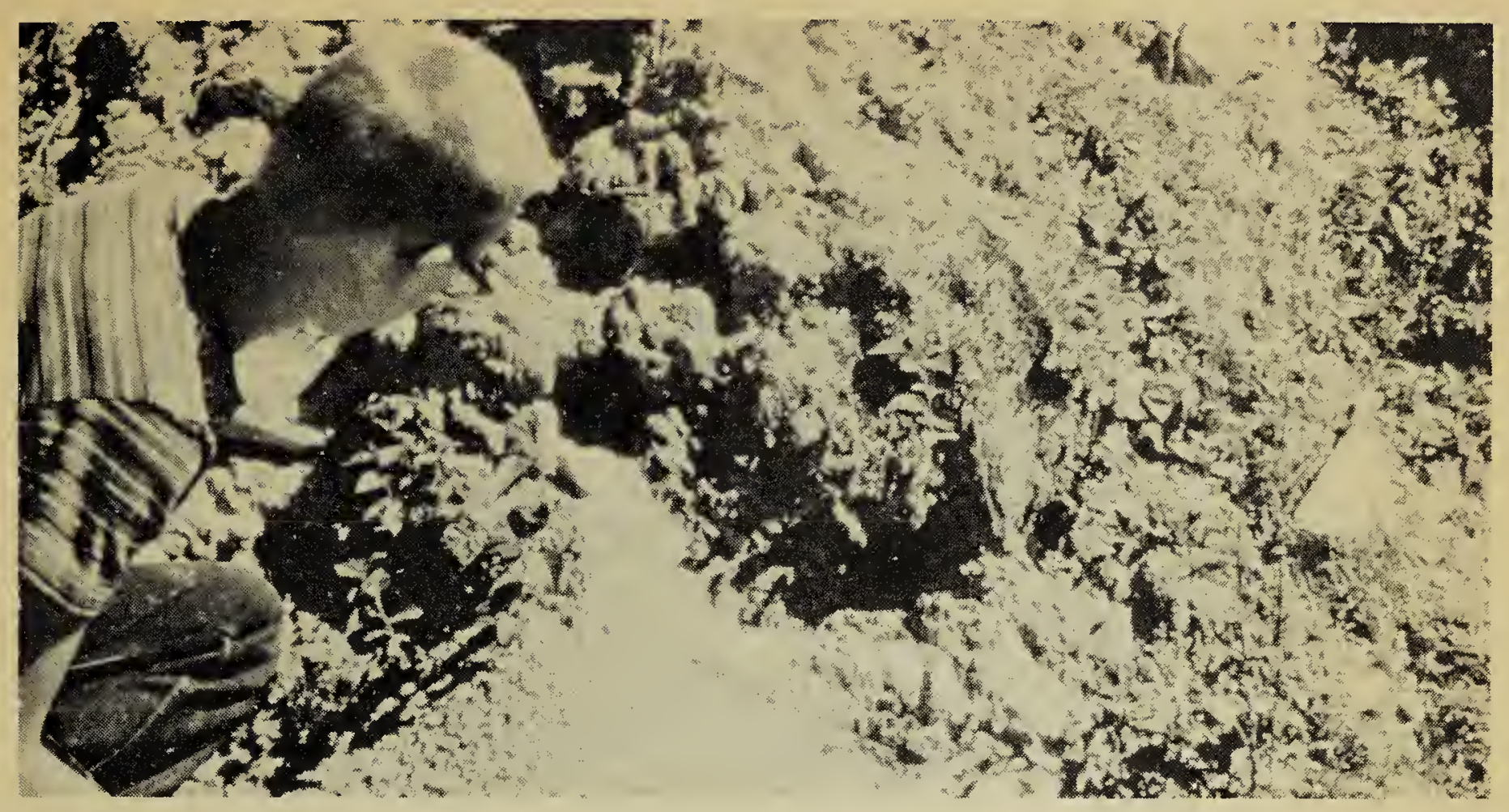

Alan Wade examining Belted Kingfisher nest hole, La Ronge-Churchill River Road

over. From La Ronge to Waskesiu we listed these birds: one Slatecolored Junco, 12 Cedar Waxwings, one Pigeon Hawk, about 20 Common Ravens, one Spruce Grouse, one dead Ruffed Grouse, one Cooper's Hawk, and (about two miles north of Waskesiu) one Black-billed Magpie.

On September 4, we were travelling from Candle Lake over to the Hanson Lake Road, cutting across on a road that runs just south of Whiteswan Lake. We then went up the Hanson Lake Road, taking a side trip into Lower Fishing Lake, the narrow Hills Tower Road, and finally back out up to Little Bear Lake. En route we saw one Black Bear, eight Whitetailed Deer, elk and moose tracks, and the following birds: many Slatecolored Juncos, three Magnolia Warblers, one Red-tailed Hawk, one Osprey, many small flocks (10 to 30 birds in a flock) of Cedar Waxwings, about 200 Myrtle Warblers (apparently coming through in large numbers), two Yellow-shafted Flickers, three Spruce Grouse hens, one Rough-legged Hawk, and one male Sparrow Hawk. At Little Bear Lake we spotted 20 Horned Larks and at the Torch River bridge on the Hanson Lake Road, eight Horned Larks.

On a previous trip to La Ronge, D. E. Wade saw a Mourning Dove fly across the road. The location was an extensive burned-over, wooded mus$\mathrm{keg}$, about 17 miles south of the town of La Ronge. On the La Ronge-
Churchill River Road, at Mile 7, on August 17, 1960, we saw an adult Belted Kingfisher fly out from a hole in a borrow-pit bank adjacent to the road (see figure). Earlier in the summer the pit had contained water, but it was dry when we saw it. The nearest water available for fishing was a creek about half a mile away. The hole was in compact sand and contained young which we could hear.

On August 18, 1960, while canoeing on MacKay Lake, we watched two Ravens harassing a Goshawk. The Goshawk successfully drove the Ravens away from a point of land above which we could see the Goshawk flying at different times while we were in viewing distance.

Both of the roads we have mentioned have penetrated wild country and there are few settlements. The Department of Natural Resources is establishing new camp sites on these roads and adjacent lakes. The road north out of La Ronge passes through Pre-Cambrian country, whereas the country traversed by the Hanson. Lake Road is largely glacial till and quite sandy in places with much muskeg. The latter road will eventually end at Creighton near Flin Flon, but will not be open for general traffic until late in 1962. Enquiries concerning these roads, canoe routes, and camping should be directed to the Department of Natural Resources, Regina. 